\title{
Influence of protamine on adhesion, chemotaxis and proliferation of human vascular smooth muscle cells
}

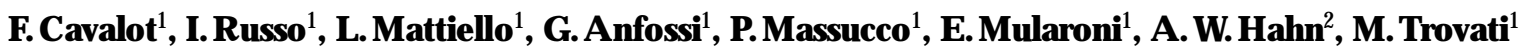 \\ ${ }^{1} \mathrm{D}$ iabetes $U$ nit, $\mathrm{D}$ epartment of $\mathrm{C}$ linical and Biological Sciences, $U$ niversity of Turin, Turin, I taly \\ ${ }^{2} \mathrm{R}$ esearch D epartment, U niversity of B asel, B asel, Switzerland
}

Summary It has been shown that, in streptozotocin diabetic rats, protamine-retarded insulin administered in vivo stimulates intimal hyperplasia in balloon-injured carotid artery. The aim of this study was to evaluate the influence of protamine on cultured human vascular smooth muscle cells (hVSMC), by observing its effects on adhesion, chemotaxis and proliferation. hVSM C were isolated during abdominal surgery, cultured and utilized at passages 6-10. We observed that protamine stimulates: 1 ) cell adhesion in the concentration range $0.04-20 \mu \mathrm{g} / \mathrm{ml}$ (analysis of variance, A N OVA , $p<0.0001$ ); 2) cell chemotaxis in the absence of fetal calf serum (FCS) in the concentration range $1-200 \mu \mathrm{g} / \mathrm{ml}$ (A NOVA, $p<0.0001$ ) and in the presence of $1 \%$ FCS in the concentration range $5-200 \mu \mathrm{g} / \mathrm{ml}$ (A N OVA , $p<0.0001$ ), further enhancing the chemotaxis induced by $10 \%$ $\mathrm{FCS}$ in the concentration range $20-200 \mu \mathrm{g} / \mathrm{ml}$ (A NOVA, $p<0.0001$ ) ; 3) cell proliferation and ${ }^{3} \mathrm{H}$ thymidine incorporation from 1 to $5 \mu \mathrm{g} / \mathrm{ml}$ (ANOVA, $p<0.0001$ ); 4) cell c-fos oncoprotein nuclear expression. We also observed that protamine effects on chemotaxis, proliferation and c-fos expression are inhibited by heparin that human insulin stimulates cell proliferation and ${ }^{3} \mathrm{H}$-thymidine incorporation (A NOVA, $p<0.0001$ ) at concentrations equal to or greater than $480 \mathrm{pmol} / \mathrm{l}$ and that these effects of insulin persist in the presence of protamine. In conclusion, protamine influences hV SM C behaviour by interfering with biological functions involved in atherogenesis. The concentrations used in this shortterm in vitro study were higher than those probably occurring in vivo in patients chronically treated by protamine-retarded insulin preparations: further studies, therefore, are needed to evaluate the safety of protamine as a retardant of insulin action in vivo. [D iabetologia (1997) 40: 67-75]

Keywords Protamine, insulin, heparin, vascular smooth muscle cells, diabetic angiopathy, atherosclerosis.
Protamine-retarded insulins are widely used in clinical practice. However, little information is available

R eceived: 23 M ay 1996 and in revised form: 19 September 1996

Corresponding author: D r. M .Trovati, D iabetes U nit, D epartment of Clinical and Biological Sciences at the U niversity of Turin, San L uigi G onzaga H ospital, 10043 O rbassano (Torino), I taly

A bbreviations: hVSM C, H uman vascular smooth muscle cells; $M E M$, minimum essential medium; $F C S$, fetal calf serum; $B S A$, bovine serum albumin; EDTA, ethylenediaminetetraacetic acid; EGTA, ethyleneglycol-bis-( $\beta$-amino-ethyl ether) $\mathrm{N}, \mathrm{N}$ '-tetraacetic acid; PBS, phosphate buffered-saline; A N O $\mathrm{VA}$, analysis of variance. on the fate of subcutaneously injected protamine. It is known that $30-50 \%$ of patients treated with protamine produce specific anti-protamine antibodies belonging to the IgG or IgE classes [1], which are responsible for the 40-50-fold increased risk of potentially lethal allergic reactions to intravenous protamine given to antagonize the anticoagulant effect of heparin during cardiovascular procedures [2]. Further studies should be undertaken to determine the amount of protamine metabolized at the injection site during chronic subcutaneous administration and the amount which enters the bloodstream, the site of in vivo protamine catabolism and the effect of the interaction between protamine and its specific 
antibodies on protamine localization at the vascular or kidney level. Without this information, it is difficult to predict the vascular concentrations of protamine in patients who have been treated daily with protamine-retarded insulin for a long time period. Since the long-acting (18-36 h) protamine-zinc insulin preparation contains about $0.3 \mathrm{mg}$ protamine per $\mathrm{mg}$ insulin and the intermediate-acting (12-24 h) neutral protamine $\mathrm{H}$ agedorn $(\mathrm{NPH})$ preparation contains about $0.1 \mathrm{mg}$ protamine per $\mathrm{mg}$ insulin, one could probably foresee a plasma concentration in the $\mathrm{ng} / \mathrm{ml}$ range after injection of an insulin-protamine preparation. It is more difficult to foresee the levels attained after a period of chronic treatment, for the reasons mentioned. The lack of interest in the fate of injected protamine reflects the common belief that it is only a retardant of insulin action.

Protamine is a basic, polycationic protein rich in arginine, whose major physiological role is to condense the DNA contained in mature spermatozoa in an insoluble complex [3]. I t is used not only to retard insulin action, but also to neutralize the anticoagulant effect of therapeutically administered heparin, an anionic glycosaminoglycan with which it interacts in a $1: 1$ ratio through its cationic sites [4]. The ability of protamine to antagonize the heparin effects should be carefully considered since heparin not only has anticoagulant properties. A ctually, endogenous heparin or heparin-like substances play an important role in maintaining the vascular smooth muscle cells (VSMC) in a quiescent growth state [5]. Heparin binds to V SM C and is internalized via a receptor-mediated endocytosis [6, 7]; within the cells, it exerts important effects on growth-related events, inhibiting both early G 0/G 1 transition [8] as well as mid-tolate $\mathrm{G} 1$ progression [9]. Furthermore, it selectively inhibits a protein kinase $\mathrm{C}$-dependent mitogenic signalling pathway, including a repression of the protooncogene c-fos induced by phorbol esters [10]; finally, it displaces mitogens, such as fibroblast growth factor, from the arterial wall [11]. G lycosaminoglycan deficiency is involved in the pathogenesis of atherosclerosis [12] and glomerular hyperpermeability in diabetes $[13,14]$; furthermore, administration of glycosaminoglycans, heparin or heparin-like substances, prevents [15] or reduces [16] the glomerular hyperpermeability of diabetic nephropathy. The fact that protamine inhibits (through its cationic sites) the effects exerted by heparin (through its anionic sites) raises therapeutic concerns, since the lack of anionic charges is considered one of the most relevant pathogenetic factors of diabetic angiopathy [12-14].

It has been impressively shown by $E$ delman et al. [17], using a model of balloon catheter injury in rats, that i) a continuous release of protamine (33$821 \mu \mathrm{g} \cdot \mathrm{kg}^{-1} \cdot$ day $^{-1}$ ) from the subcutaneous tissue for 1 week before and 2 weeks after arterial injury increases intimal hyperplasia and cell proliferation and antagonizes the heparin-induced inhibition of intimal growth; ii) exposure of rat aortic V SM C to 1-10 $\mathrm{gg} /$ $\mathrm{ml}$ protamine enhances cell proliferation and inhibits the anti-proliferative effect of heparin; iii) in streptozotocin diabetic rats, neointimal hyperplasia after carotid injury, which is dramatically lower than in control animals, is increased by the administration of cristalline insulin $\left(40 \mathrm{U} \cdot \mathrm{kg}^{-1} \cdot\right.$ day $\left.^{-1}\right)$ slightly, but not significantly, whereas protamine-zinc insulin administration $\left(20 \mathrm{U} \cdot \mathrm{kg}^{-1} \cdot\right.$ day $\left.^{-1}\right)$ increases neointimal hyperplasia 5.2-fold; the effects on cell proliferation, however, do not linearly correspond to those on vascular injury exacerbation, suggesting a role for protamine in V SM C migration. In summary, in rats protamine al one or protamine-insulin preparations induce proliferative responses of V SM C that are typical of the atherosclerotic process [18]. It should be considered that the doses of protamine/zinc insulin used in the rats were much higher than those usually administered in humans ( $20 \mathrm{vs} 0.6 \mathrm{U} \cdot \mathrm{kg}^{-1} \cdot$ day $^{-1}$ maximum); the protamine doses were also much higher (about $300 \mathrm{vs} 8 \mu \mathrm{g} \cdot \mathrm{kg}^{-1} \cdot$ day $^{-1}$ maximum).

This important study in rats compelled us to evaluate the effects of protamine on human VSMC (hVSM C). In particular, we aimed to investigate a) whether protamine influences not only hV SM C proliferation, but also c-fos oncoprotein expression, adhesion and chemotaxis; b) whether the protamine effects on hV SM C are antagonized by heparin.

Furthermore, protamine has been described to inhibit platelet-derived growth factor receptor activity [19] an the mitogenic properties of the extracellular matrix and fibroblast growth factor [20], whereas it potentiates those of epidermal growth factor [20]. These effects are interesting per se: for instance, probably owing to its ability to inhibit some growth factors involved in angiogenesis, protamine shows anti-angiogenetic properties [21]. Insulin is able to stimulate V SM C proliferation [22]; it is not known, however, whether protamine interferes with this property of insulin. In this study, therefore, we aimed to investigate whether protamine enhances, reduces or simply does not affect the proliferative activity of insulin.

\section{Materials and methods}

Culture of hVSM C. M icroarterioles for isolation of hVSM C were obtained from a single non-diabetic, normotensive, heart disease free patient undergoing abdominal surgery. The cells for culture were prepared as described and shown to accumulate acetylated low density lipoproteins, and to stain positively with smooth muscle alpha-actin antibody, but negatively with Factor VIII antibody [23]. These cells have previously been shown in our laboratory to adhere and proliferate on fibronectin in adhesion and proliferation assays [24] and to produce endothelin [25]. The cells were grown in M inimum Essential Medium (MEM) supplemented with $10 \mathrm{mmol} / \mathrm{L} \mathrm{L}$-glutamine, $10 \mathrm{mmol} / \mathrm{l}$ (N-tris [hydroxymethyl]-methyl-2-aminoethane- 
sulphonic acid (TES)/4-(2-hydroxyethyl)-I-piperazine ethane sulphonic acid (HEPES), $100 \mathrm{U} / \mathrm{ml}$ penicillin and streptomycin, $1 \mathrm{mmol} / \mathrm{l}$ sodium pyruvate and $10 \%$ fetal calf serum (FCS), all from Boehringer Mannheim (Mannheim, Germany). Confluent cells were passaged by trypsynization and were utilized at passages 6 - 10 for the experimental procedures.

A dhesion assay with hVSM C. The assay was performed as described by Bourdon and Ruoslathi [26]. Ninety-six-well polystyrene plates (Sterilin Limited, H ounslow, UK) were coated with protamine (Salmon Protamine, Sigma, St.Louis, M o., USA) by dissolving the protein (concentration range 0.04$20 \mu \mathrm{g} / \mathrm{ml}$ ) in distilled water and adding $50 \mu \mathrm{l}$ of the protein solution per well. The plates were then dried overnight under a sterile hood and blocked with MEM plus $0.25 \%$ bovine serum albumin (BSA) for $1 \mathrm{~h}$ at $37^{\circ} \mathrm{C}$. Subconfluent monolayer cultures were harvested by treatment with Trypsin/EDTA / E GTA $(0.05 / 0.1 / 0.01 \%)$, washed once with MEM plus $0.25 \%$ BSA and the cells were resuspended in ME M plus $0.1 \%$ BSA at $5 \times 10^{5} / \mathrm{ml}$. O ne hundred microlitres of cell suspension was added to the coated wells and incubated for $2 \mathrm{~h}$ to allow adhesion of cells. A the end of incubation, the wells were washed three times with $0.2 \mathrm{ml} /$ well of phosphate buffered saline (PBS), the adherent cells were fixed to the substratum using $3.5 \%$ formaldehyde in PBS for 10 min and stained with $0.5 \%$ toluidine blue in PBS. The cells were lysed with $100 \mu \mathrm{l} / \mathrm{well}$ $1 \%$ sodium dodecyl-sulphate and the optical density read at $620 \mathrm{~nm}$ in the E lisa reader. The intra-assay coefficient of variation for the adhesion assay was less than $5 \%$ and the inter-assay coefficient of variation was less than $10 \%$ at the concentrations tested. In the experiments where the dose-response curve for the adhesion was evaluated, protamine at each concentration ranging from $40 \mathrm{ng} / \mathrm{ml}$ to $20 \mu \mathrm{g} / \mathrm{ml}$ was tested in six wells per plate; four plates were used per experiment, and the experiments were repeated three times.

To show the appearance of hV SM C when plated on protamine, pictures of the cells that had been allowed to adhere for $2 \mathrm{~h}$ were taken with an inverted microscope at $100 \times$ magnification. A s a negative control, pictures of hV SM C that had been allowed to adhere for $2 \mathrm{~h}$ in uncoated and blocked wells were taken.

To evaluate an eventual ability of insulin as a coating agent, the hormone (R ecombinant $\mathrm{H}$ uman Insulin, Calbiochem, La Jolla, Calif., USA) was prepared at concentrations ranging from $240 \mathrm{pmol} / \mathrm{l}$ to $15.72 \mathrm{nmol} / \mathrm{l}$ and $50 \mu \mathrm{l}$ were added per well; subsequently the plates were treated as previously described.

Chemotaxis assay. The assay was conducted in 48-well chemotaxis chambers ( N europrobe, B ethesda, M d., U SA ). E ach well consists of a lower part in which the solutions of chemoattractants are placed, and of an upper part where the cell suspensions are placed. The lower and upper parts are separated by polycarbonate filters with 8- $\mu \mathrm{m}$ pores coated with Type $1 \mathrm{col}-$ lagen at $10 \mu \mathrm{g} / \mathrm{ml}$. In a first set of experiments, the cell suspensions were prepared at $5 \times 10^{5} / \mathrm{ml}$ in MEM plus $0.1 \%$ BSA and protamine was added to ME M plus $0.1 \%$ BSA, at concentrations ranging from 1 to $200 \mu \mathrm{g} / \mathrm{ml}$. In a second set of experiments, designed to evaluate whether protamine is able to increase chemotaxis of hVSMC in the presence of a low serum concentration, both the chemotactic solution and the cell suspension were prepared in MEM plus $1 \%$ FCS and protamine was added to the chemotactic solution at concentrations ranging from 5 to $200 \mu \mathrm{g} / \mathrm{ml}$. In a third set of experiments, designed to evaluate whether protamine is able to increase chemotaxis induced by serum, the chemotactic solution was prepared with MEM plus $10 \%$ FCS and protamine was added at concentrations ranging from 20 to $200 \mu \mathrm{g} / \mathrm{ml}$, while the cells were suspended in M E M plus $0.1 \%$ BSA . A s negative control for chemoattractants ME M plus $0.1 \%$ BSA was used, while as positive control MEM plus $10 \%$ FCS was used; in both cases the cells were suspended in M E M plus $0.1 \%$ BSA . To evaluate the inhibitory effect of heparin on chemotaxis induced by protamine, heparin (E parina Vister, sodium salt, $150 \mathrm{IU} / \mathrm{mg}$; Parke-D avis, B arcelona, Spain) at $200 \mu \mathrm{g} / \mathrm{ml}$ was added to the chemotatic solution containing protamine at $200 \mu \mathrm{g} / \mathrm{ml}$.

To evaluate the eventual effect of insulin on chemotaxis, the hormone was added to the chemotactic solution, both with and without $1 \%$ or $10 \% \mathrm{FCS}$, at concentrations ranging from $240 \mathrm{pmol} / \mathrm{l}$ to $15.72 \mathrm{nmol} / \mathrm{l}$, either alone or in addition to protamine at the concentration of 10 and $200 \mu \mathrm{g} / \mathrm{ml}$.

A fter assembling, the chambers were incubated at $37^{\circ} \mathrm{C}$ in $5 \% \mathrm{CO}_{2}$ for $8 \mathrm{~h}$. Finally the chambers were disassembled, the filters were fixed in methanol and stained with $\mathrm{H}$ arris' haematoxylin and eosin. The cells in the upper part of the filter were removed, while the cells that had migrated to the lower part of the filter were counted. Four $400 \times$ fields per well were counted, three wells were tested in each experiment per each concentration and the experiments were repeated four times. In our laboratory, intra-assay coefficient of variation for the chemotaxis assay was less than $10 \%$, while the inter-assay coefficient of variation was less than $20 \%$ at the concentrations tested.

Proliferation assays. Proliferation of hVSMC was tested by counting the number of cells and by evaluating thymidine incorporation.

Cell count. The cell proliferation assay was conducted in 24well plates by seeding $10^{4} \mathrm{hV} \mathrm{SM} \mathrm{C} \mathrm{per} \mathrm{well} \mathrm{in} \mathrm{M} \mathrm{E} \mathrm{M} \mathrm{plus} 10 \%$ FCS. A fter $24 \mathrm{~h}$, the medium was changed to MEM plus $1 \%$ FCS and maintained for $48 \mathrm{~h}$. A t the end of this period, the MEM plus $1 \%$ FCS was replaced with the same medium and the various substances were added at the specified concentrations: protamine from 1 to $5 \mu \mathrm{g} / \mathrm{ml}$, heparin at 5 and $10 \mu \mathrm{g} / \mathrm{ml}$, insulin from 60 to $1920 \mathrm{pmol} / \mathrm{l}$, protamine at $5 \mathrm{\mu g} / \mathrm{ml}$ plus heparin at 5 or $10 \mu \mathrm{g} / \mathrm{ml}$, protamine at 1 and $2 \mu \mathrm{g} / \mathrm{ml}$ plus insulin from 240 to $1920 \mathrm{pmol} / \mathrm{l}$. A fter $48 \mathrm{~h}$ the medium was replaced together with the additions just described. A fter an additional overnight incubation, the cells were trypsinized and the number of cells per well was counted in a haemocytometer, performing two counts per well. E ach concentration was tested in quadruplicate and the experiments were repeated three times. Proliferation experiments employing cell counting showed an intra-assay coefficient of variation less than $5 \%$ and an interassay coefficient less than $10 \%$.

Thymidine incorporation assay. The thymidine incorporation assay was conducted in 24-well plates by seeding $10^{4} \mathrm{hV} \mathrm{SM} \mathrm{C}$ per well in MEM plus $10 \% \mathrm{FCS}$. A fter $24 \mathrm{~h}$, the medium was changed to MEM plus $1 \%$ FCS and maintained for $48 \mathrm{~h}$. A t the end of this period, the MEM plus 1\% FCS was replaced with the same medium and the various substances were added at the same concentrations specified for the proliferation assay: protamine from 1 to $5 \mu \mathrm{g} / \mathrm{ml}$, heparin at 5 and $10 \mu \mathrm{g} / \mathrm{ml}$, insulin from 60 to $1920 \mathrm{pmol} / /$, protamine at $5 \mu \mathrm{g} / \mathrm{ml}$ plus heparin at 5 or $10 \mu \mathrm{g} / \mathrm{ml}$, protamine at 1 and $2 \mu \mathrm{g} / \mathrm{ml}$ plus insulin from 240 to $1920 \mathrm{pmol} / \mathrm{l}$. A fter $48 \mathrm{~h}$ the M EM plus $1 \%$ FCS was replaced and the various test substances and tritiated thymidine (methyl- ${ }^{3} \mathrm{H}$-thymidine, $20 \mathrm{Ci} / \mathrm{mmol}$; D u Pont de $\mathrm{N}$ emours I taliana, $\mathrm{M}$ ilan, I taly) at $1 \mu \mathrm{Ci} / \mathrm{ml}$ were added. Following a further 15-h incubation, the medium was removed, the wells were washed with $2 \mathrm{ml} \mathrm{H}$ ank's B alanced Salt Solution, then with $2 \mathrm{ml}$ of $10 \%$ ice-cold trichloroacetic acid for $10 \mathrm{~min}$. A fter two additional 5-min washes with trichloroacetic acid, the cell monolayers were dissolved with $500 \mu \mathrm{l} /$ well $1 \%$ sodium dodecyl- 
sulphate in $0.3 \mathrm{~mol}$ sodium hydroxide and the radioactivity evaluated in a beta counter (Packard Instrument B .V., G roningen, The N etherlands). E ach concentration was tested in quadruplicate and the experiments were repeated three times. Proliferation experiments employing thymidine incorporation showed an intra-assay coefficient of variation less than $5 \%$ and an inter-assay coefficient less than $10 \%$.

I mmunofluorescence staining. I n order to evaluate the effect of protamine on c-fos oncogene expression, the cells were incubated with MEM plus $1 \%$ FCS for $48 \mathrm{~h}$ on cover-glasses in six-well plates. A fter this period, the medium was replaced with MEM plus $1 \%$ FCS and various test substances added: protamine at $5 \mu \mathrm{g} / \mathrm{ml}$, protamine at $5 \mu \mathrm{g} / \mathrm{ml}$ plus heparin at $20 \mu \mathrm{g} / \mathrm{ml}$. The incubation was maintained for $1,2,6$, and $24 \mathrm{~h}$. Finally, the medium was removed, the wells were washed with PBS, the cells were fixed with acetone-methanol $(9: 1)$ at $-20^{\circ} \mathrm{C}$, rehydrated with $\mathrm{PBS}$, and finally stained with a sheep antibody to C-fos oncoprotein (C ambridge R esearch B iochemicals, Wilmington, Del., U SA ) followed by a fluorescein isothyocianate-conjugated rabbit antibody to sheep IgG (Sigma, St. L ouis, M o., U SA ). The coverslips were then mounted on a slide and observed in a fluorescence microscope. Each slide was read independently by three researchers and a semiquantitative score was assigned to each slide.

\section{Statistical analysis}

R esults are expressed as mean \pm SE M. Statistical evaluation was performed by means of analysis of variance (A NOVA); pairwise comparisons were evaluated by means of Fisher's least significant difference [27]. Statistical calculations were elaborated utilizing the program StatV iew 4.01 (A bacus Concepts Inc., B erkeley, Calif., U SA ) for the M acintosh computer.

\section{Results}

Adhesion. Protamine promoted the attachment of hV SM C to the substrate and induced the formation of a cell monolayer (Fig. 1A); in the absence of a coating agent no cells attached to the polystyrene plates (Fig. 1B). The phenomenon of adhesion to protamine showed a dose dependency (Fig.2) $(p<0.0001)$ : the effect of protamine was detected starting from $40 \mathrm{ng} / \mathrm{ml}$ coating concentration. Insulin at physiological or supraphysiological concentrations ranging from $240 \mathrm{pmol} / \mathrm{l}$ to $15.72 \mathrm{nmol} / \mathrm{l}$ did not induce adhesion of hVSM C ( $p=N S)$.

Chemotaxis. Protamine by itself stimulated chemotaxis of hV SM C (Fig. 3): the effect was present when protamine wasincubated in the absence of FCS at concentrationsfrom 1 to $200 \mu \mathrm{g} / \mathrm{ml}(p<0.0001)$ (Fig. 3A ). The effect of protamine at concentrations ranging from 5 to $200 \mu \mathrm{g} / \mathrm{ml}$ was also detected when the assay was conducted in the presence of $1 \%$ FCS added both to the cell suspension and to the chemoattractant solution ( $p<0.0001$ ) (Fig. 3B). When protamine was added to the chemoattractant solution together with $10 \%$ FCS, it enhanced the chemotactic effect of $10 \%$

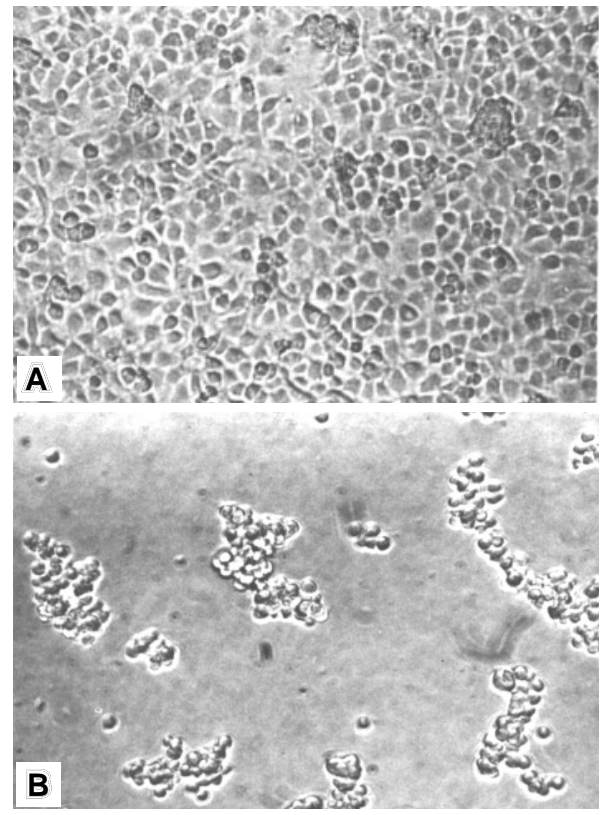

Fig. 1. A. hVSM C adhering to protamine at $1 \mu \mathrm{g} / \mathrm{ml}$; cells appear as a homogeneous monolayer with an enlarged cytoplasm. B. In the absence of protamine, the cells do not adhere to the wells, do not expand their cytoplasm and form aggregates. Photographs taken in an inverted microscope at $100 \times$ magnification

FCS at concentrations ranging from 20 to $200 \mu \mathrm{g} / \mathrm{ml}$ $(p<0.0001)$ (Fig. 3C). The chemotactic effect of protamine alone, of protamine in the presence of $1 \%$ FCS or the stimulating effect of protamine on chemotaxis induced by $10 \%$ FCS were inhibited by heparin at equivalent concentrations: Figure 3 shows the results for protamine $200 \mu \mathrm{g} / \mathrm{ml}$ and heparin $200 \mu \mathrm{g} / \mathrm{ml}$.

Insulin at concentrations ranging from $240 \mathrm{pmol} / \mathrm{l}$ to $15.72 \mathrm{nmol} / \mathrm{l}$ did not affect chemotaxis in the experimental conditions examined (without FCS, with $1 \%$ and with $10 \% \mathrm{FCS})(\mathrm{p}=\mathrm{NS})$; furthermore, chemotaxis induced by protamine was absolutely unchanged in the presence of insulin, even at the highest concentration tested $(p=N S)$.

Proliferation. Protamine dose-dependently stimulated cell proliferation, evaluated by cell counting, starting from 1 up to $5 \mu \mathrm{g} / \mathrm{ml}(\mathrm{p}<0.0001)$ (Fig. 4A). Protamine dose-dependently stimulated the incorporation of tritiated thymidine by hVSMC from 1 to $5 \mu \mathrm{g} / \mathrm{ml}(\mathrm{p}<0.0001)$ (Fig.4B).

Heparin alone inhibited cell proliferation evaluated by counting the number of cells $(p=0.008)$ (Fig. 4A) and measuring thymidine incorporation $(p=0.0001)$ (Fig. 4B). The stimulating effect of protamine at $5 \mu \mathrm{g} / \mathrm{ml}$ on cell number (Fig. $4 \mathrm{~A}$ ) and thymidine incorporation was inhibited by heparin at 5 and $10 \mu \mathrm{g} / \mathrm{ml}$ (Fig.4B) ( $p<0.0001$ both for cell number and thymidine incorporation). When hVSM C were incubated with protamine at $5 \mu \mathrm{g} / \mathrm{ml}$ plus heparin at 


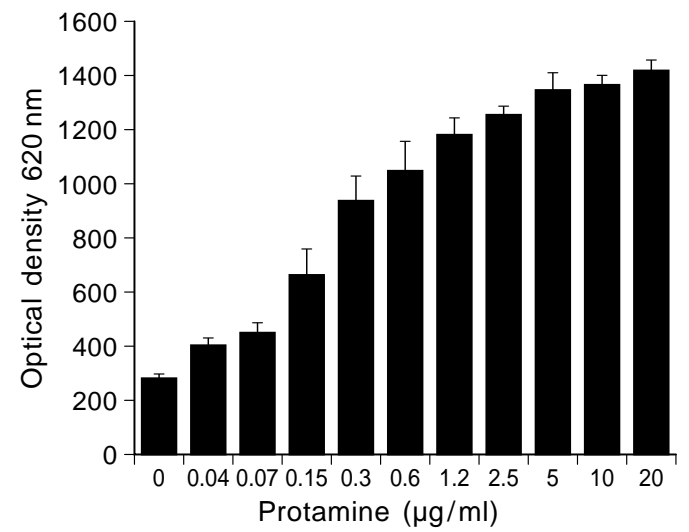

Fig. 2. Effect of protamine on hVSMC adhesion. Protamine dose-dependently stimulates the adhesion of hV SM C (A NO $\mathrm{VA}: \mathrm{p}<0.0001)$

$5 \mu \mathrm{g} / \mathrm{ml}$ or with protamine at $5 \mu \mathrm{g} / \mathrm{ml}$ plus heparin at $10 \mu \mathrm{g} / \mathrm{ml}$, the cell proliferation was higher than when the cells were incubated with heparin alone both by cell counting (at $5 \mu \mathrm{g} / \mathrm{ml}, p=0.0045$, and at $10 \mu \mathrm{g} / \mathrm{ml}$, $p=0.0369$, respectively) (Fig. 4A) and by thymidine incorporation (at $5 \mu \mathrm{g} / \mathrm{ml}, \mathrm{p}=0.0024$, and at $10 \mu \mathrm{g} /$ $\mathrm{ml}, \mathrm{p}=0.022$, respectively) (Fig. 4B).

Insulin itself induced a slight but significant proliferation of hVSMC as evaluated by cell counting $(p<0.0001)$ (Fig.5A) and thymidine incorporation $(p<0.0001)$ (Fig. 5B). The effect on cell counts and on thymidine incorporation was significant starting from $480 \mathrm{pmol} / \mathrm{l}$.

When insulin at 240, 480, 960 and $1920 \mathrm{pmol} / \mathrm{l}$ was added to protamine at $1 \mu \mathrm{g} / \mathrm{ml}$, its effects on hV SM C counts and on thymidine incorporation were significant $(p=0.0013$ and $p=0.0007$, respectively) (Fig. 6). Similar effects were obtained with protamine $2 \mu \mathrm{g} / \mathrm{ml}(p=0.0179$ and $p=0.0024$, respectively).

I mmunofluorescence staining for c-fos. hV SM C maintained in 1\% FCS and stained for c-fos oncoprotein showed weak nuclear staining (Table 1). Cells incubated with protamine at $5 \mu \mathrm{g} / \mathrm{ml}$ showed strong nuclear staining for the c-fos oncoprotein after the first two hours of incubation; later, the staining became weaker. When protamine at $5 \mu \mathrm{g} / \mathrm{ml}$ was incubated in the presence of heparin at $20 \mu \mathrm{g} / \mathrm{ml}$, the nuclei of hV SM C did not stain for c-fos oncoprotein.

\section{Discussion}

The present study shows that: 1) protamine induces the adhesion of hVSMC in the absence of FCS. 2) Protamine acts as a chemotactic agent for hVSM C, both in the absence and in the presence of FCS, and enhances the chemotaxis induced by $10 \%$ FCS. 3) Protamine stimulates the proliferation of hV SM C, as shown by cell counting and by thymidine
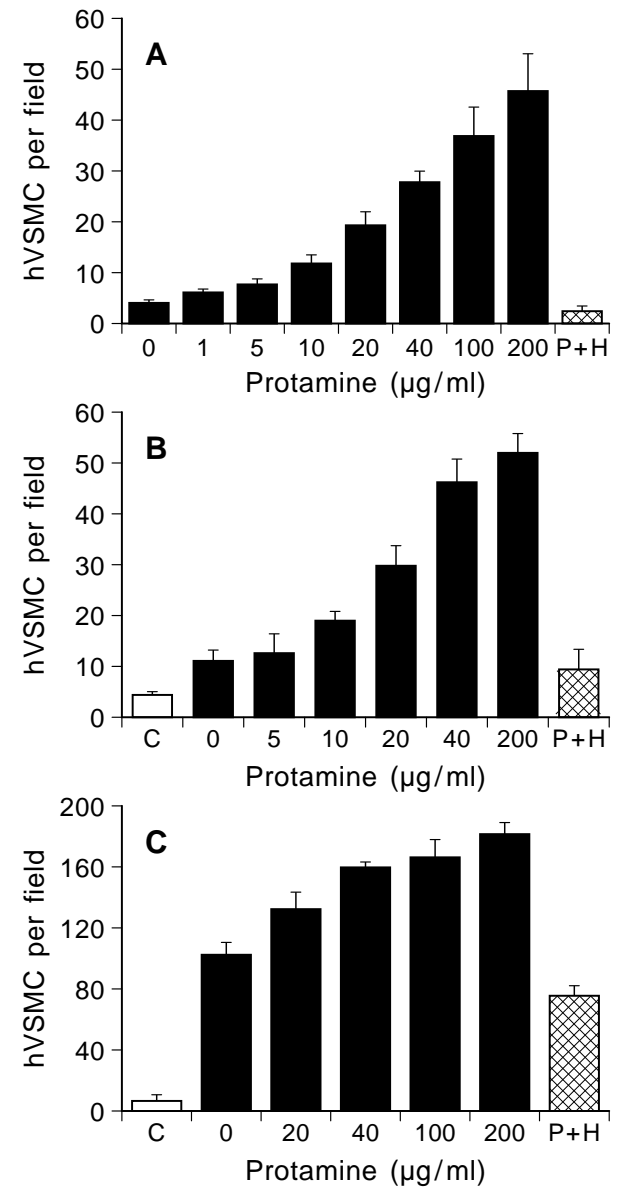

Fig. 3. (A-C) Effect of protamine on hV SM C chemotaxis. A. Protamine dose-dependently stimulates the chemotaxis of hV SMC starting from $1 \mu \mathrm{g} / \mathrm{ml}$. (A NOVA: $p<0.0001$ ). The chemotactic effect of protamine at $200 \mu \mathrm{g} / \mathrm{ml}$ is inhibited by heparin at $200 \mu \mathrm{g} / \mathrm{ml}$ ( added to the chemotactic solution B.Protamine dose-dependently stimulates the chemotaxis of hV SM C in the presence of $1 \%$ fetal calf serum added both to chemotactic solution and to cell suspension starting from $5 \mu \mathrm{g} / \mathrm{ml}$ ( A N OVA : $p<0.0001$ ). The chemotactic effect of protamine at $200 \mu \mathrm{g} / \mathrm{ml}$ is inhibited by heparin at $200 \mu \mathrm{g} / \mathrm{ml}$ ( $)$ added to the chemotactic solution $\mathbf{C}$. Protamine dose-dependently stimulates the chemotaxis induced by $10 \%$ fetal calf serum starting from $20 \mu \mathrm{g} / \mathrm{ml}$ (A NOVA : $p<0.0001$ ). The effect of protamine at $200 \mu \mathrm{g} / \mathrm{ml}$ is inhibited by heparin at $200 \mu \mathrm{g} / \mathrm{ml}$ $(\otimes)$ added to the chemotactic solution. $\mathrm{P}+\mathrm{H}$, Protamine at $200 \mu \mathrm{g} / \mathrm{ml}+\mathrm{H}$ eparin at $200 \mu \mathrm{g} / \mathrm{ml}$

incorporation, and induces c-fos oncoprotein expression. 4) Heparin inhibits the hVSM C proliferation induced by FCS, the chemotactic and proliferative effects of protamine, and the protamine ability to activate c-fos oncoprotein expression. 5) At very high physiological $(\sim 480 \mathrm{pmol} / \mathrm{l})$ and supraphysiological ( $\geq 960 \mathrm{pmol} / \mathrm{l}$ ) concentrations, insulin slightly stimulates hVSMC proliferation and thymidine incorporation, whereas, even at highly supraphysiological concentrations, it does not affect hV SM C adhesion or chemotaxis. 6) In the presence of protamine, the effects of insulin on hV SM C proliferation remain significant. 

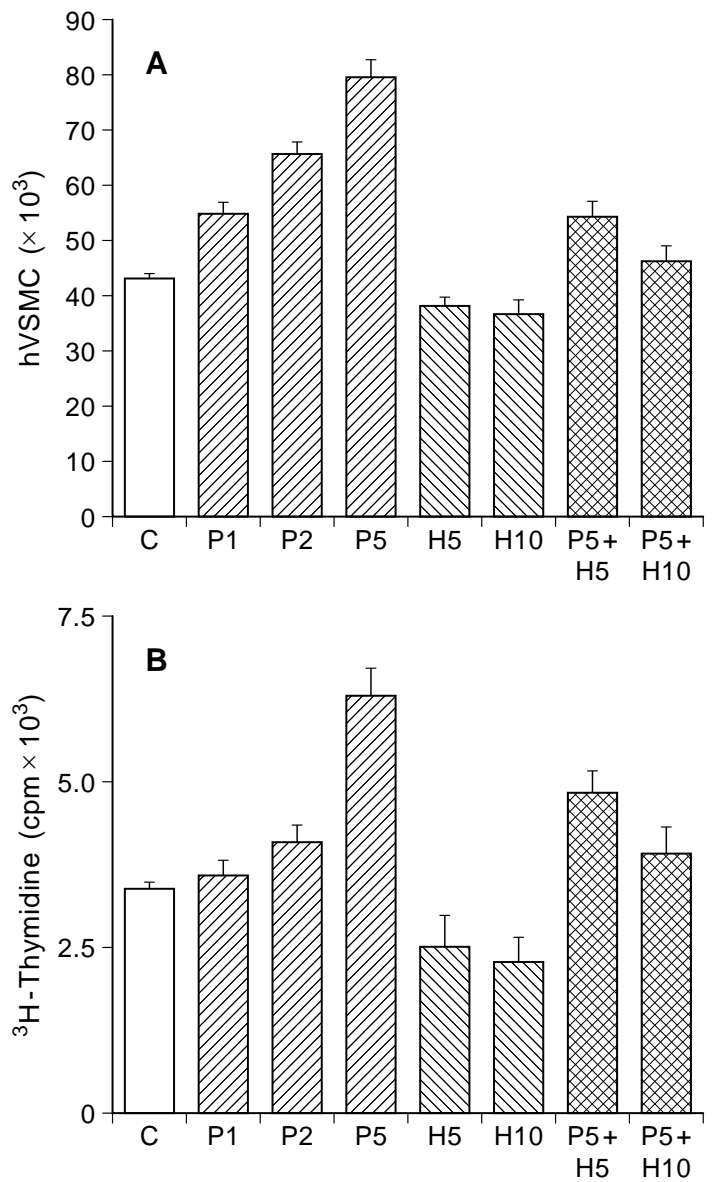

Fig. 4. (A , B) Effect of protamine and heparin on hV SM C proliferation. A. Protamine dose-dependently increases hV SM C counts (A N OVA : $p<0.0001$ ). H eparin inhibits basal hV SM C counts (A NOVA: $p=0.008$ ). The stimulating effect of protamine at $5 \mu \mathrm{g} / \mathrm{ml}$ on hV SM C counts is inhibited by heparin at 5 and $10 \mu \mathrm{g} / \mathrm{ml}(p<0.0001)$. When hV SM C are incubated with protamine $5 \mu \mathrm{g} / \mathrm{ml}$ + heparin $5 \mu \mathrm{g} / \mathrm{ml}$, or with protamine $5 \mu \mathrm{g} /$ $\mathrm{ml}+$ heparin $10 \mu \mathrm{g} / \mathrm{ml}$, the number of cells that proliferate is higher than when the cells are incubated with heparin alone at $5 \mu \mathrm{g} / \mathrm{ml}(p=0.0045)$ or at $10 \mu \mathrm{g} / \mathrm{ml} \quad(p=0.0369)$, respectively. B. Protamine dose-dependently stimulates thymidine incorporation by hV SM C (A N OVA : p < 0.0001). Heparin inhibits basal incorporation of tritiated thymidine by hVSMC (A NOVA: $p=0.0001$ ). The effect is significant at 5 and at $10 \mu \mathrm{g} / \mathrm{ml}(p=0.039$ and $p=0.0027$, respectively). The stimulating effect of protamine at $5 \mathrm{mg} / \mathrm{ml}$ on tritiated thymidine incorporation in hVSM C is inhibited by heparin at 5 and $10 \mu \mathrm{g} / \mathrm{ml}$ $(p=0.0001)$. When hV SM C are incubated with protamine at $5 \mu \mathrm{g} / \mathrm{ml}+$ heparin at $5 \mu \mathrm{g} / \mathrm{ml}$, or with protamine at $5 \mu \mathrm{g} /$ $\mathrm{ml}+$ heparin at $10 \mu \mathrm{g} / \mathrm{ml}$, tritiated thymidine incorporation is higher than in the presence of heparin alone at $5 \mu \mathrm{g} / \mathrm{ml}$ $(p=0.0024)$ or at $10 \mu \mathrm{g} / \mathrm{ml}(p=0.022)$, respectively. $C$, Control; P, protamine $(\mu \mathrm{g} / \mathrm{ml}) ; \mathrm{H}$, heparin $(\mu \mathrm{g} / \mathrm{ml})$

A sfar as we know, this is the first study to evaluate the effects of protamine on hVSMC. We employed hV SM C taken from arterioles, and not from aorta or its main branches, which are the vascular segments more prone to atherosclerosis, only because it is very difficult to obtain specimens of these arteries from non-atherosclerotic subjects, and we aimed to study
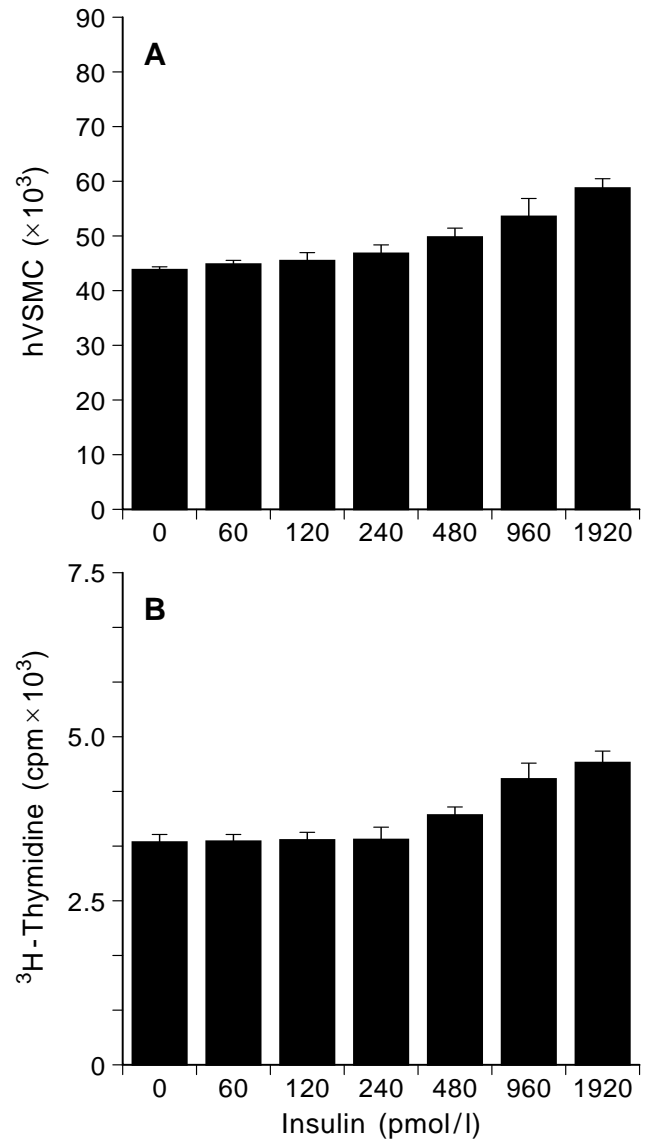

Fig.5. (A, B) Effect of insulin on hVSMC proliferation. A. Insulin increases hVSMC counts (A NOVA: $p<0.0001$ ). When each concentration is evaluated independently, the effect is significant at $480 \mathrm{pmol} / \mathrm{l} \quad(p=0.024), 960 \mathrm{pmol} / \mathrm{l}$ $(p<0.0001)$ and $1920 \mathrm{pmol} / \mathrm{l}(\mathrm{p}<0.0001)$. B. Insulin stimulates thymidine incorporation by hVSMC (ANOVA: $p<0.0001)$. When each concentration is evaluated independently, the effect of insulin is significant at $480 \mathrm{pmol} / \mathrm{l}$ $(p=0.05)$ and increases with increasing insulin concentrations: at $960 \mathrm{pmol} / \mathrm{l}, \mathrm{p}=0.0007$, at $1920 \mathrm{pmol} / \mathrm{l}, \mathrm{p}<0.0001$

cells not affected by pathological changes. We cannot exclude, however, that cells from large arteries would show a different sensitivity to the proliferative effects of protamine or insulin.

The sensitivity of our cells to protamine is very similar to that of rat aortic cells [17] as far as proliferation is concerned, since protamine concentrations equator greater than $1 \mu \mathrm{g} / \mathrm{ml}$ are required.

A s far as we know, this is the first study taking into account the direct protamine effects on V SM C adhesion and chemotaxis; therefore, we are not able to compare the protamine doses we used with those of other studies. The protamine concentrations capable of increasing hV SM C adhesion are relatively low, in the $\mathrm{ng} / \mathrm{ml}$ range, and this fact could have some relevance for effects in patients treated with protamineretarded insulin.

Protamine concentrations utilized for the chemotaxis assay seem to be elevated when compared to those 

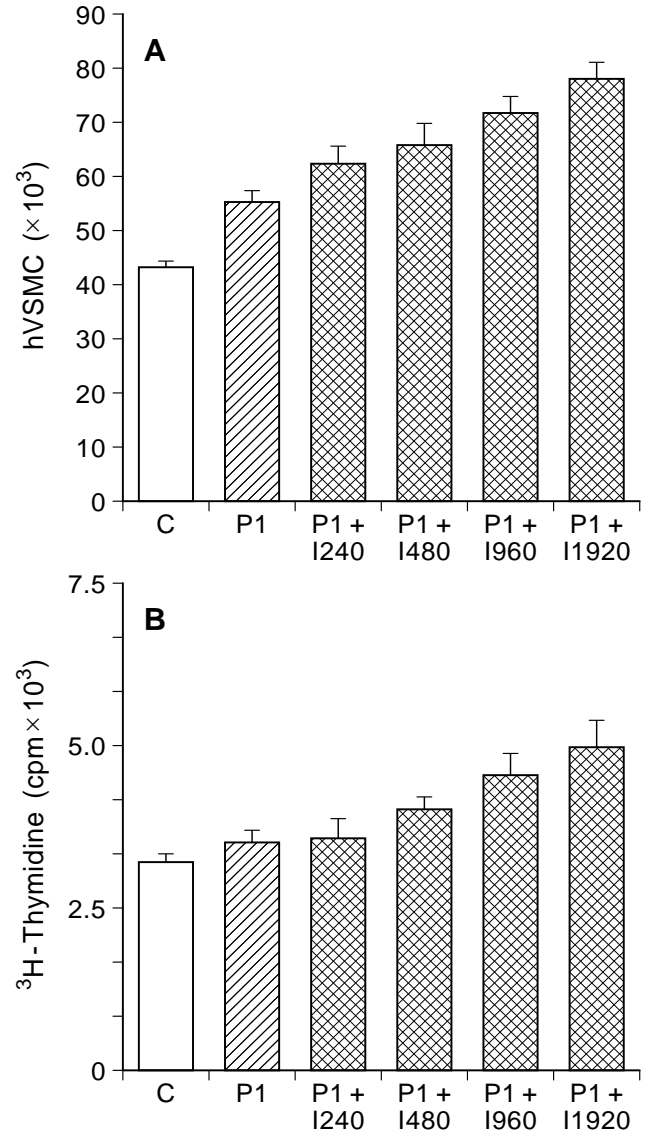

Fig. 6. (A , B ) Effect of insulin + protamine on hV SM C proliferation. A. When insulin at $240,480,960$ and $1920 \mathrm{pmol} / \mathrm{l}$ is added to protamine at $1 \mu \mathrm{g} / \mathrm{ml}$, the increase of hV SM C count induced by insulin is significant (A NOVA: $p=0.0013$ ) B. When insulin at $240,480,960$ and $1920 \mathrm{pmol} / \mathrm{l}$ is added to protamine at $1 \mu \mathrm{g} / \mathrm{ml}$, the increase of thymidine incorporation induced by insulin is significant (A NOVA : $p=0.0007$ ). C, C ontrol; P, protamine $(\mu \mathrm{g} / \mathrm{ml})$; I, insulin $(\mathrm{pmol} / \mathrm{l})$

active on adhesion and proliferation; however, it has been observed that the concentrations of chemotactic substances present on the upper surface of the filters and able to activate chemotaxis are as low as one-fifth of those added to the lower chamber [28]: thus, the concentrations of protamine active on chemotaxisare similar to those that induce adhesion and proliferation.

This study shows that protamine is able to modify cultured hVSMC chemotaxis and proliferation features in acute experiments at concentrations that are probably higher than those attained in vivo, even if specific studies are needed to define the therapeutic protamine concentrations reached in chronically treated patients.

The second part of the discussion considers the possible mechanisms involved in the protamine actions we observed.

The process of adhesion is necessary in V SM C, as in other anchorage-dependent cells, for normal cell functions, i. e. the ability to structure the cytoskeleton, to alkalize intracellular $\mathrm{pH}$, to contract in response to
Table 1. E ffect of protamine and protamine plus heparin on nuclear expression of c-fos oncoprotein by hVSM C evaluated by indirect immunofluorescence

\begin{tabular}{lllll}
\hline Incubation time $(\mathrm{h}):$ & 1 & 2 & 6 & 24 \\
\hline Fetal calf serum $1 \%$ & $+/-$ & $+/-$ & $+/-$ & $+/-$ \\
Protamine $5 \mu \mathrm{g} / \mathrm{ml}$ & $+/++$ & $++/+++$ & ++ & $+/++$ \\
Protamine $5 \mu \mathrm{g} / \mathrm{ml}+$ & & & & \\
H eparin $20 \mu \mathrm{g} / \mathrm{ml}$ & $+/-$ & - & - & - \\
\hline
\end{tabular}

mediators like angiotensin II, to migrate, and finally, to proliferate in response to mitogenic stimuli [29]. In the present study we showed that in vitro protamine directly interacts with hV SM C, allowing adhesion to the substrate at nanomolar concentrations suggesting a high affinity of protamine for the cell surface. This effect of protamine is not surprising, since other cationic molecules, such as polylysine, are able to increase cell adhesion; for instance, packed human erythrocytes are attached to polylysine-coated polyacrylamide beads so firmly that the further lysis of attached cells leaves the beads covered by plasma membranes [30]. A ctually, the high positive charges of polycationic molecules facilitate the interaction with the negative charges of the cell surfaces and of extracellular matrix. Protamine itself has been used to interact with the anionic charges of glomerular basement membranes, a specialized type of extracellular matrix [31]. O ther cationic proteins also interact with the glomerular wall when injected in vivo $[32,33]$.

A s far as chemotaxis is concerned, we showed that protamine stimulates hV SM C chemotaxis both with and without serum. V SM C migration from the media to the intima in response to chemotactic substances, such as platelet-derived growth factor and other factors derived from platelets and macrophages, plays a key role in the formation of the atherosclerotic plaque [18]. Protamine could take part in this process both through a direct activation of chemotaxis and/or interplay with the effects of other agents. For instance, protamine has been shown to interfere in different ways with the receptors of different growth factors $[19,20]$. H owever, the dose-response effect of protamine-induced chemotaxis up to the huge dose of $200 \mu \mathrm{g} / \mathrm{ml}$ in the absence of FCS, suggests an active role for protamine on its own in V SM C chemotaxis.

A s far as hVSM C proliferation is concerned, we observed that protamine stimulates both the increase of cell number and the incorporation of tritiated thymidine. Furthermore, we demonstrated for the first time that protamine stimulates c-fos oncoprotein expression. The effect on hV SM C proliferation is present at a low FCS concentration ( $1 \%)$, which is enough to allow the survival of the cells, but minimizes the effect of serum itself.

Protamine presents different mechanisms by which it could affect VSMC proliferation: 1) it 
interacts with growth factor receptors, which are glycoproteins containing negatively charged carbohydrate moieties, decreasing the action of some growth factors and increasing that of others $[19,20] ; 2$ ) it reduces the well-known antiproliferative effects of heparin or heparin-like substances [17], the mechanisms of which have already been extensively described in the introduction; 3 ) it could also modulate cell proliferation on its own.

VSMC produce heparin-like compounds that inhibit their proliferation [34]; in our study, however, the dose-response relationship of the protamine effects on cell proliferation even when high doses are reached does not exclude the presence of an active role for protamine on its own on V SM C proliferation.

The reciprocal interactions between heparin and protamine, on the other hand, are particularly interesting, as pointed out in the introduction. We have already mentioned that heparin specifically represses cfos mR NA induced by phorbol-esters, but not by epidermal growth factor, suggesting that it selectively inhibits a protein kinase $\mathrm{C}$-dependent mitogenic signalling pathway [10]. The heparin effect on c-fos is closely associated with its growth-inhibitory activity, since heparin does not suppress c-fos mR NA induction in cells derived from a strain of rats resistant to its antiproliferative effects [10]. O ur observation that heparin suppresses the c-fos oncoprotein expression activated by protamine in hV SM C could be due to an effect of heparin on this proto-oncogene, or to the fact that heparin counteracts the interaction of protamine with the cells by means of a charge mechanism, and, consequently, blocks any protamine-mediated intracellular event.

In this study, we also evaluated the effects of insulin on hV SM C. Insulin has been previously described as a potentially atherogenic hormone since it not only stimulates V SM C proliferation, but also activates the $\mathrm{Na}^{+} / \mathrm{H}^{+}$antiporter, increases V L D L synthesis and deposition in the vessel wall and the cholesterol transport in the VSMC, and enhances the sympathetic tone [35]. On the other hand, insulin, through nitric oxide, exerts beneficial vasodilating [36-38] and platelet anti-aggregating $[39,40]$ properties, that are lost in the hyperinsulinaemic, insulin-resistant states $[41,42]$, inducing us to speculate that the resistance to beneficial vascular effects of insulin could also play a role in the pathogenesis of arterial hypertension and atherosclerosis. A $n$ open question is whether the proliferative effects described in cultured V SM C in vitro are reproducible in man when physiological insulin concentrations are attained in vivo, where they could be attenuated by nitric oxide-dependent mechanisms mediated by other cell types, such as endothelial cells and platelets. In our study, insulin was only able to stimulate hV SM C proliferation from the concentration of $480 \mathrm{pmol} / \mathrm{l}$, i.e., in the very high postprandial range. On the other hand, even at very high, non-physiological concentrations (see $15.72 \mathrm{nmol} / \mathrm{l})$, it was unable to stimulate adhesion and chemotaxis of hVSM C. When protamine, at active concentrations, was added to insulin, it showed additive effects. It is very important to note that in our experiments the relative concentrations of insulin and protamine are different on a per weight basis than those usually employed in insulin/protamine preparations, protamine being present in much higher doses. Therefore, our results do not support the conclusion that protamine increases the proliferative effects of insulin in the clinical setting. The meaning of these experiments is that protamine, which reduces the effects of some growth factors and increases those of others $[19,20]$, neither reduces nor potentiates the proliferative effects of insulin.

The present study, carried out as a short-term experiment in vitro in cultured hV SM C, does not prove that protamine is atherogenic at clinical doses as a retardant of insulin preparations: actually, we evidenced proliferative effects starting from $1 \mu \mathrm{g} / \mathrm{ml}$, whereas the circulating range of protamine concentrations reached in vivo should be of $\mathrm{ng} / \mathrm{ml}$ at maximum. O ur study, however, supports the conclusion that protamine, commonly used as a retardant of insulin action, should not be considered inert or neutral from the vascular point of view.

It is known that endogenous heparin-like substances play a pivotal role in protection against vasculopathy in vivo [5], and that their lack in diabetic patients contributes to the pathogenesis of angiopathy [12-14]: for these reasons, our study does not exclude that protamine concentrations reached in vivo after daily administration, for years and decades, could antagonize the protective actions of endogenous heparin-like molecules, inhibiting the already deficient vascular repair provided by these substances in patients at high risk of developing atherosclerosis.

In conclusion, this work could stimulate further research aiming to elucidate whether protamine is actually able to influence the evolution of diabetic angiopathy.

\section{References}

1. Nell LJ, Thomas JW (1988) Frequency and specificity of protamine antibodies in diabetic and control subjects. D iabetes 37: 172-176

2. Weiss ME, Nyhan D, Peng Z et al. (1989) A ssociation of protamine IgE and IgG antibodies with life-threatening reactions to intravenous protamine. N Engl J M ed 320: 886892

3. G atewood J M, Schroth GP, Schmid CW, Bradbury EM (1990) Zinc-induced secondary structure transitions in human sperm protamines. J Biol Chem 265: 20667-20672

4. L owary LR, Smith FA, Coyne E, Dunham NW (1971) Comparative neutralization of lung- and mucosal-derived heparin by protamine sulfate using in vitro and in vivo methods. J Pharm Sci 60: 638-640 
5. Karnovsky M J, W right TC, Castellot J J, Choay J, L ormeau JC, Petitou M (1989) Heparin, heparan sulfate, smooth muscle cells, and atherosclerosis. A nn NY A cad Sci 556P: 268-281

6. Letourneur D, Caleb BL, Castellot JJ (1995) H eparin binding, internalization, and metabolism in vascular smooth muscle cells. I. U pregulation of heparin binding correlates with antiproliferative activity. J Cell Physiol 165: 676-686

7. L etourneur D, Caleb BL, C astellot JJ (1995) H eparin binding, internalization, and metabolism in vascular smooth muscle cells. II. Degradation and secretion in sensitive and resistant cells. J Cell Physiol 165: 687-695

8. Castellot JJ, Cochran D, K arnovsky M J (1985) Effects of heparin on vascular smooth muscle cells. I. Cell metabolism. J Cell Physiol 124: 21-28

9. Castellot J J, Pukac LA , Caleb B L, W right TC, K arnovsky MJ (1989) H eparin selectively inhibits a protein kinase Cdependent mechanism of cell cycle progression in calf aortic smooth muscle cells. J Cell B iol 109: 3147-3155

10. Pukac LA , Castellot J J, W right TC, Caleb BL, Karnovsky MJ (1990) $\mathrm{H}$ eparin inhibits c-fos and c-myc mRNA expression in vascular smooth muscle cells. Cell Regul 1: 435-443

11. Lindner V, O Ison NE, Clowes A W, R eidy M A (1992) Inhibition of smooth muscle cell proliferation in injured rat arteries. Interaction of heparin with basic fibroblast growth factor. J Clin Invest 90: 2044-2049

12. Wasty F, A lavi M Z, M oore S (1993) D istribution of glycosaminoglycans in the intima of human aortas: changes in atherosclerosis and diabetes mellitus. Diabetologia 36: 316-322

13. Parthasarathy N, Spiro R G (1982) E ffect of diabetes on the glycosaminoglycan component of human glomerular basement membrane. Diabetes 31: 738-741

14. Shimonura H, Spiro R G (1987) Studies on macromolecular components of human glomerular basement membrane and alterations in diabetes. D iabetes 36: 374-381

15. Gambaro G, Venturini A P, Noonan DM et al. (1994) Treatment with a glycosaminoglycan formulation ameliorates experimental diabetic nephropathy. Kidney Int 46: 797-806

16. M yrup B, H ansen PM, Jensen T et al. (1995) E ffect of lowdose heparin on urinary albumin excretion in insulin-dependent diabetes mellitus. L ancet 345: 421-422

17. E delman ER, Pukac LA , K arnovsky MJ (1993) Protamine and protamine-insulins exacerbate the vascular response to injury. J Clin Invest 91: 2308-2313

18. R oss R (1993) The pathogenesis of atherosclerosis: a perspective for the 1990s. Nature 362: 801-809

19. H uang J S, Nishimura J, H uang SS, D euel TF (1984) Protamine inhibits platelet derived growth factor receptor activity but not epidermal growth factor activity. J Cell Biochem 26: 205-220

20. Neufeld G, G ospodarowicz D (1987) Protamine sulfate inhibits mitogenic activities of the extracellular matrix and fibroblast growth factor, but potentiates that of epidermal growth factor. J Cell Physiol 132: 287-294

21. Taylor S, Folkman J (1982) Protamine is an inhibitor of angiogenesis. Nature (L ondon) 297: 307-312

22. Stout RW (1990) Insulin and atheroma. 20-Y ear perspective. Diabetes Care 13: 631-654

23. Scott-B urden T, Resink TJ, H ahn A WA, Baur U, Box RJ, Buehler FR (1989) Induction of growth-related metabolism in human vascular smooth muscle cells by low density lipoprotein. J Biol Chem 264: 12582-12589
24. Cavalot F, A nfossi G, R usso I et al. (1996) Non-enzymatic glycation of fibronectin impairs adhesive and proliferative properties of human vascular smooth muscle cells. M etabolism 45: 285-292

25. A nfossi G, Cavalot F, M assucco P et al. (1993) Insulin influences immunoreactive endothelin release by human vascuIar smooth muscle cells. M etabolism 42: 1081-1083

26. Bourdon MA , R uoslathi E (1989) Tenascin mediates cell attachment through an RGD-dependent receptor. J Cell Biol 108: 1149-1155

27. Winer BJ (1971) Statistical principles in experimental design. M CG raw-Hill, N ew York

28. L auffenberger DA, Zigmond SH (1981) Chemotactic factor concentration gradients in chemotaxis assay systems. J Immunol Meth 40: 45-60

29. Juliano R L (1987) Membrane receptors for extracellular matrix macromolecules: relationship to cell adhesion and tumor metastasis. B iochim B iophys A cta 907: 261-278

30. Jacobson BS, B ranton D (1977) Plasma membrane: rapid isolation and exposure of the cytoplasmic surface by use of positively charged beads. Science 195: 302-304

31. V haskari V M, R oot E R, G ermuth F G, R obson A M (1982) G lomerular charge and urinary protein excretion: effects of systemic and intrarenal polycation infusion in the rat. Kidney Int 22: 127-135

32. Cavalot F, M yiata M, V ladutiu A et al. (1992) G lomerular lesions induced in the rabbit by physico-chemically altered homologous I gG. A m J Pathol 140: 581-600

33. A ndres $G$, $Y$ uzawa $Y, C$ avalot $F$ (1988) R ecent progress in renal immunopathology. H uman Pathology 19: 1132-1143

34. Fritze LM S, R eilly CF, R osenberg R (1985) A $n$ antiproliferative heparan sulfate species produced by postconfluent smooth muscle cells. J Cell Biol 100: 1041-1049

35. DeFronzo R A, Ferrannini E (1991) Insulin resistance: a multifaceted syndrome responsible for NIDDM, obesity, hypertension, dyslipidemia, and atherosclerotic cardiovascular disease. D iabetes Care 14: 173-194

36. Steinberg H O, B rechtel G, J ohnson A, Fineberg N, B aron A (1994) Insulin-mediated skeletal muscle vasodilation is nitric oxide dependent. A novel action of insulin to increase nitric oxide release. J Clin Invest 94: 1172-1179

37. Scherrer U, R andin D, Vollenweider P, Nicod P (1994) N itric oxide release accounts for insulin's vascular effects in humans. J Clin Invest 94: 2511-2515

38. Trovati M, M assucco P, M attiello L, Cavalot F, M ularoni E, A nfossi G (1995) Insulin increases cyclic nucleotide content in human vascular smooth muscle cells: a mechanism potentially involved in insulin-induced modulation of vascular tone. D iabetologia 38: 936-941

39. Trovati M, A nfossi G, Cavalot F, M assucco P, Mularoni E, E manuelli $G$ (1988) Insulin directly reduces platelet sensitivity to aggregating agents. Studies in vitro and in vivo. Diabetes 37: 780-786

40. Trovati M, M assucco P, M attiello L et al. (1996) The insulin-induced increase of guanosine-3',5'-cyclic monophosphate in human platelets is mediated by nitric oxide. Diabetes 45: 768-770

41. Vollenweider $P, R$ andin $D$, Tappy L, Jequier E, Nicod P, Scherrer U (1994) Impaired insulin-induced sympathetic neural activation and vasodilation in skeletal muscle in obese humans. J Clin Invest 93: 2365-2371

42. Trovati M, M ularoni E, B urzacca S et al. (1995) I mpaired insulin-induced platelet anti-aggregating effect in obesity and in obese non-insulin-dependent diabetes mellitus. Diabetes 44: 1318-1322 